\title{
REMEDIATING BIOFOULING OF REVERSE OSMOSIS MEMBRANES (U)
}

by

\author{
J. L. Siler
}

Westinghous: Savannah River Company

Savannah River Site

Aiken, Sou'h Carolina 29808

\section{DISCLAIMER}

\begin{abstract}
This report was prepared as an account of work sponsored by an agency of the United States Government. Neither the United States Government nor any agency theroof, nor any of their employees, makes any warranty, expreas or implied, or assumes any legal liability or responsi. bility for the accuracy, completeness, or usefulness of any information, apparatus, product, or process disclosed, ot represents that its use would not infringe privately owned rights. Referonce herein to any specific commercial product, process, or service by trade name, trademark, manufacturer, or otherwise does not necessarily constitute or imply its endotsement, recommendation, or favoring by the United States Government or any agency thereof. The views and opinions of authors expressed herein do not secsissarily state or reflect those of the Unitad States Government or any agency thereof.
\end{abstract}

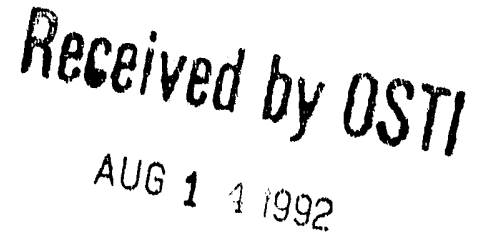

$\therefore$

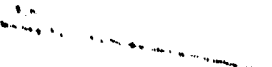

This report was prepared in connection with work done under Contract No. DE-AC09-89SR18035 with the U.S. Department of Energy. By acceptance of this report, the publisher and/or recipient acknowledges the U.S. Government's right to retain a nonexclusive, royalty-free license in and to any copyright covering this report, along with the right to reproduce and to authorize others to reproduce all or part of the copyrighted report. 


\section{DISCLAIMER}

This report was prepared as an account of work sponsored by an agency of the United States Government. Neither the United States Government nor any agency thereof, nor any of their employees, makes any warranty, express or implied, or assumes any legal liability or responsibility for the accuracy, completeness, or usefulness of any information, apparatus, product, or process disclosed, or represents that its use would not infringe privately owned rights. Reference herein to any specific commercial product, process, or service by trade name, trademark, manufacturer, or otherwise does not necessarily constitute or imply its endorsement, recommendation, or favoring by the United States Government or any agency thereof. The views and opinions of authors expressed herein do not necessarily state or reflect those of the United States Government or any agency thereof.

This report has been reproduced directly from the best available copy.

Available to DOE and DOE contractors from the Office of Scientific and Technical Information, P.O. Box 62, Oak Ridge, TN 37831; prices available from (615) 576-8401, FTS 626-8401.

Available to the public from the National Technical Information Service, U.S. Department of Commerce, 52.85 Port Royal Rd., Springfield, VA 22161. 
Westinghouse Sarannah River Company

KSRC-RP-91-1059

Savannah River Laboratory

Keywords: Membrane Fouling,

Bacteria, Feed pH, Sodium

Bisulfite, Sodium Hexa

Metaphosphate, F/H ETE,

Reverse Osmosis, Water Elux,

Salt Rejection, DF

Retention Time: Permanent

October 22,1991

To: D. I. Fish, 773-A

From: J. L. Siler, 676-T

Remediating Bicfouling of Reverse Osmesis Membranes $(U)$

\section{SUMMARY}

Several potential additives and the use of influent pH adjustment were examined to remediate the biofouling problem of the ETE reverse osmosis (RO) system. Tests were conducted with simulated Ro feed containing salt, metal hyaroxides and bacteria. The addition of sodium hexametaphosphate (SHMP), sodium bisulfite, and adjusting the influent $\mathrm{pH}$ to 3 were each successful in reducing the RO biofouling. Little or no benefit was found from the use of a biofilm remover (Filmtec Alkaline Cleaner) or the use of surfactants (Surfynol or sodium lauryl sulfate). In addition, surfynol use resulted in irreversible fouling and necessitated membrane replacement.

At the water recoveries used in the ETF (>90\%), sodium bisulfite addition resulted in the recovery of 70-90\% of the flux and almost complete restoration of the DF to prefouled conditions. SHMP also produced complete restoration of the DF but flux recovery was somewhat less than with bisulfite. Adjustment of the influent $\mathrm{pH}$ to 3 recovered approximately $50 \%$ of the lost water flux but improved the DF over the initial prefouled conditions.

Based on the bench-scale tests completed, IWT would recommend that sodium bisulfite addition be tested at the ETE. This testing would involve optimizing the amount of bisulfite required. In addition, it is recommended that the addition of sHMP or influent $\mathrm{pH}$ adjustment be evaluated since the relative differences in labscale tests were imall and scale-up effects could be present. The ETF operating permit allows each to be added.

\section{INTRODUCTION}

Biofouling of the ETF RO membranes [e.g., Siler (1991a), (1991b)] has been confirmed and quantified under ideal laboratory conditions. Since chemically cleaning the membranes has been 
ineffective at restoring and maintaining $R O$ performance, a solution was needed to reduce the adsorption and fouling potential of the bacteria in the ETF feed.

Several pretreatment chemistry changes are available to the membrane process. Simple feed $\mathrm{pH}$ adjustment often corrects a difficult processing problem. It was postulated that the colloidal metals/bacteria complex could be altered by dissolving the colloids at low $\mathrm{pH}$ or modifying them at high pH. Changes in the metals/bacteria matrix should reduce the fouling potential.

The use of antiscalents, such as sodium hexametaphosphate (SHMP), could possibly reduce the adsorption potential of bacteria on the membrane surface. Antiscalents work by two mechanisms: 1) by providing a lubricant coating for the membrane surface and 2) by forming a complex with the species in solution. These two mechanisms work to produce larger, less adhering molecules in solution, which should improve RO performance.

Another potential method is to add sodium bisulfite to the membrane feed. Sodium bisulfite is well-known to reduce biofouling in Dupont Permasep TM membrane applications [see Applegate (1987)]. The Dupont membrane has a similar structure to the Filmtec membranes in use at the ETF, and thus the potential for enhanced performance was postulated.

\section{EXPERIMENTAL PROCEDURE}

The basic experimental procedure was outlined in report. \#WSRC-RP91-431. Detailed operating instructions can be found in TNX operating procedure \#679T90039.

The bisulfite experiment required the neutralization of the solution after the bisulfite was added. Addition of bisulfite resulted in the solution $\mathrm{pH}$ dropping to about 3 , which results in artificialiy high solution conductivities, particularly for permeate samples. The other feed additives did not require any further solution modification.

\section{RESULTS A.ND DISCUSSION}

\section{Sodium Bisulfite Addition}

A comparison of the successful remediation strategies is given in Figures 1-3. The addition of $500 \mathrm{mg} / 1$ sodium bisulfite resulted in $90 \%$ flux restoration at lower water recoveries and 70-80\% at high water recoveries. Processing a pure salt solution subsequent to the bisulfite test showed that there was no permanent flux loss. All. of the lost DE was restored (Eigure 2) when bisulfite was added.

The routine use of $500 \mathrm{mg} / \mathrm{l}$ sodium bisulfite would be impractical from a reagent standpoint. This amount was chosen simply to determine whether this reagent would benefit performance. 
Additional testing at SRI or at the ETF to optimize the amount would be the next logical step.

\section{Sodium Hexamatophesphate (SHMP) Addition}

The use of SHMP to remediate the biofouling resulted in about $50 \%$ improvement in the water flux (Eigure 1). About 5-8\% flux loss remained after the simulant was replaced with a pure salt solution. Here again complete restoration of the lost DF occurred (Eigure 2).

This small flux loss could be restored by cleaning the membrane with $0.1 \% \mathrm{NaOH}(\mathrm{pH}=12)$ at $200 \mathrm{psi}$ and $35^{\circ} \mathrm{C}$. Also, any flux losses that occur while processing bacteria can be offset by increasing the feed pressure.

\section{seed of Adiustment}

The feed $\mathrm{pH}$ was reduced to 3 to determine whether performance would improve as the metals were redissolved into solution. The flux results obtained were very similar to those noted for SHMP (Eigure 1). Approximately 10-12各 flux loss remained when a pure salt solution was subsequently processed. This would mean that slight increases in the Ro feed pressure would be required to maintain throughput. The flux could be restored by cleaning the membrane with $\mathrm{NaOH}$.

The DE results are shown in Eigure 3 . These results were plot.ted on a separate graph, because these tests were performed on a different Filmtec membrane module which had lower intrinsic salt rejection (e.g., $R=98.5 \%$ as compared to 99.2\%). The DE values will be substantially different, because $D F$ is related to salt rejection by

$$
D F=\frac{1}{1-R}
$$

and thus small changes in the salt rejection will be magnified in the computation of DF as the salt rejection values approach 100 . The positive aspect of this test was higher $D F$ values were obtained at higher water recoveries, and that little if any DF loss remained when a pure salt solution was subsequently processed.

Adjusting the feed $\mathrm{pH}$ to 11 was also tested. The flus remained high after bacteria were added to the solution. However, little improvement in the observed DFs was noted.

\section{other Additives}

Little improvement was noted when Surfynol, sodium lauryl sulfate, or Filmtec Alkaline Cleaner were tested at biofouling remediation. 
In fact, the use of Surfynol resulted in irreversible flux and DF loss and necessitated membrane change. Both sodium laury. sulfate and the Filmtec cleaner resulted in about 20-30\% DE loss in a pure salt solution following the bacteria testing. Also, the Filmtec cleaner resulted in 10-40\% additional flux loss on the pure salt solution. The flux and DF losses that occurred from using the Filmtec cleaner and the sodium lauryl sulfate could be restored via cleaning the membrane with $\mathrm{NaOH}$.

\section{Bating the Various Additives}

The best performance occurred when using sodium bisulfite. Very little flux loss occurred, also salt DF was unaffected by the presence of bacteria when bisulfite was used.

Adjusting the feed $p H$ or SHMP addjtion was not as successful at flux restoration, but salt DE was very good.

All three of these process changes are readily implementable at the ETE, since the permit allows for these changes.

\section{CONCIUSIONS AND RECOMMENDATIONS}

Three viable improvements to the kiofouling problem with the ETF RO system have been developed. Addition of sodium bisulfite resulted in the best overall membrane performance. However, the performance enhancements noted for SHMP and pH adjustment also look very promising.

Eventual testing of all three process changes is recommended due to the small-scale nature of the tests discussed heretofore, and possible scale up/fresh feed questions are difficult to answer. The ETF operating permit includes SHMP and bisulfite addition, thus the implementation should be straightforward. The potential performance improvements could restore the ETF RO system to its design capacity.

\section{QUALITY ASSURANCE}

The work described in this report was performed according to the guidelines in the SRS QA manual. The data collected during these tests were recorded in laboratory notebook \#WSRC-NB-90-257.

\section{REERRENCES}

Applegate, L. E., Erkenbrecher, Jr., C. W., "Monitoring and Control of Biological Activity in permasep ${ }^{\circledR}$ Seawater Ro Plants", Desalination, 65, pp. 331-359, 1987.

Siler, J. L., "The Influence of Bacteria on Reverse Osmosis Performance at the $F / H$ Effluent Treatment Eacility - A Preliminary Investigation(U)", WSRC-RP-91-431, April 10, 1991. 
Siler, J. L., "The Effect of Bacteria and Low Concentrations of Sparingly-Soluble Inorganics on Reverse Osmosis Performance at the E/H Effluent Treatment Eacility(U)", WSRC-RP-91-780, August 1, 1991 .

CC: W. I. Tomasaitis, 773A

S. T. Wach, $703 \mathrm{H}$

I. K. Sullivan, $703 \mathrm{H}$

D. F. Brown, $703 \mathrm{H}$

M. Goodman, 703H-ETE

P. M. Staph, 703H-ETE

A. W. Wiggins, 703H-ETE

D. J. McCabe, $676 \mathrm{~T}$

M. R. Poirier, $676 \mathrm{~T}$

I. I. Kilpatrick, 676T

SRI Records (4), 773A 


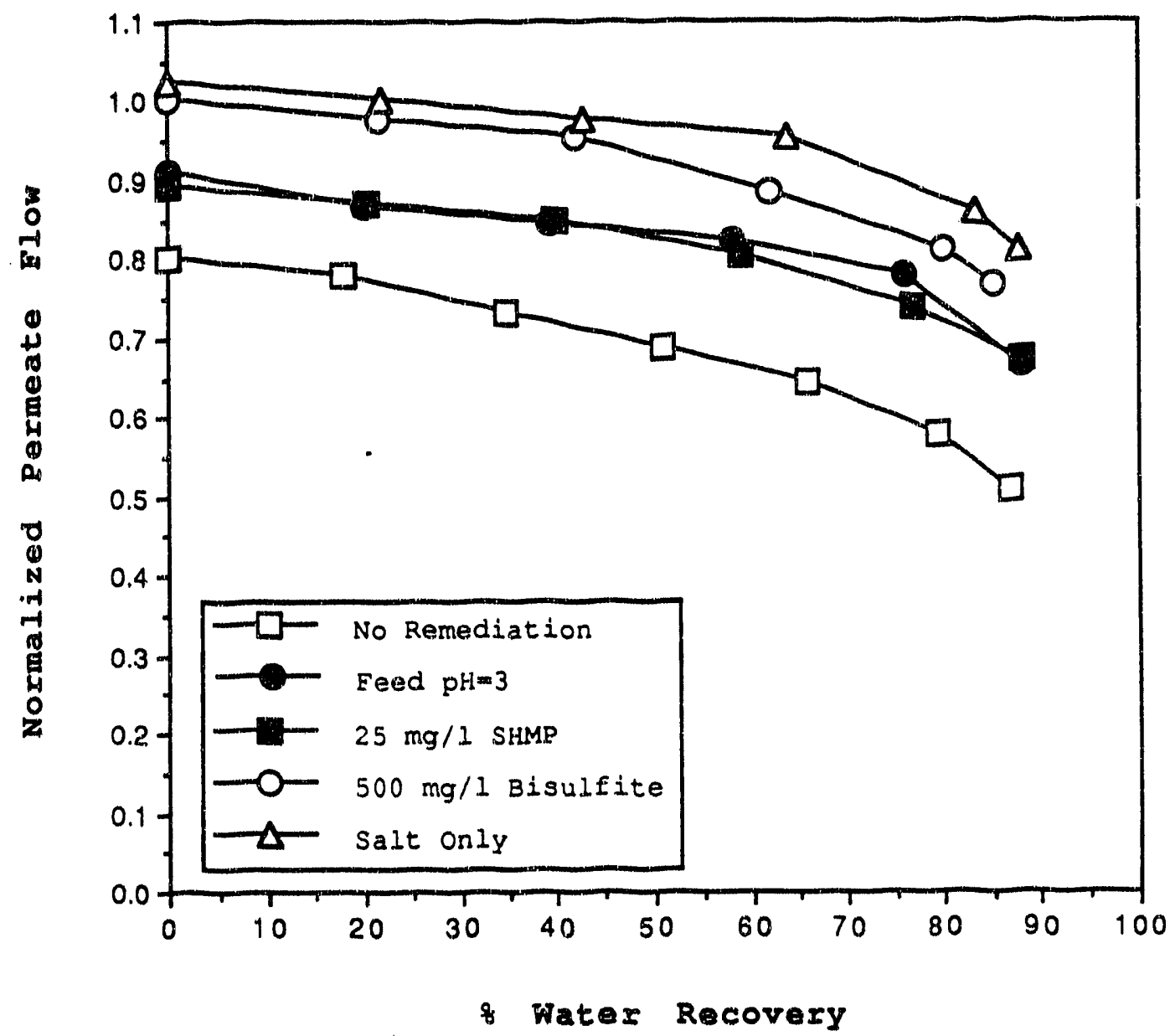

Figure 1. Remediation of Flux Losses due to Biofouling. 


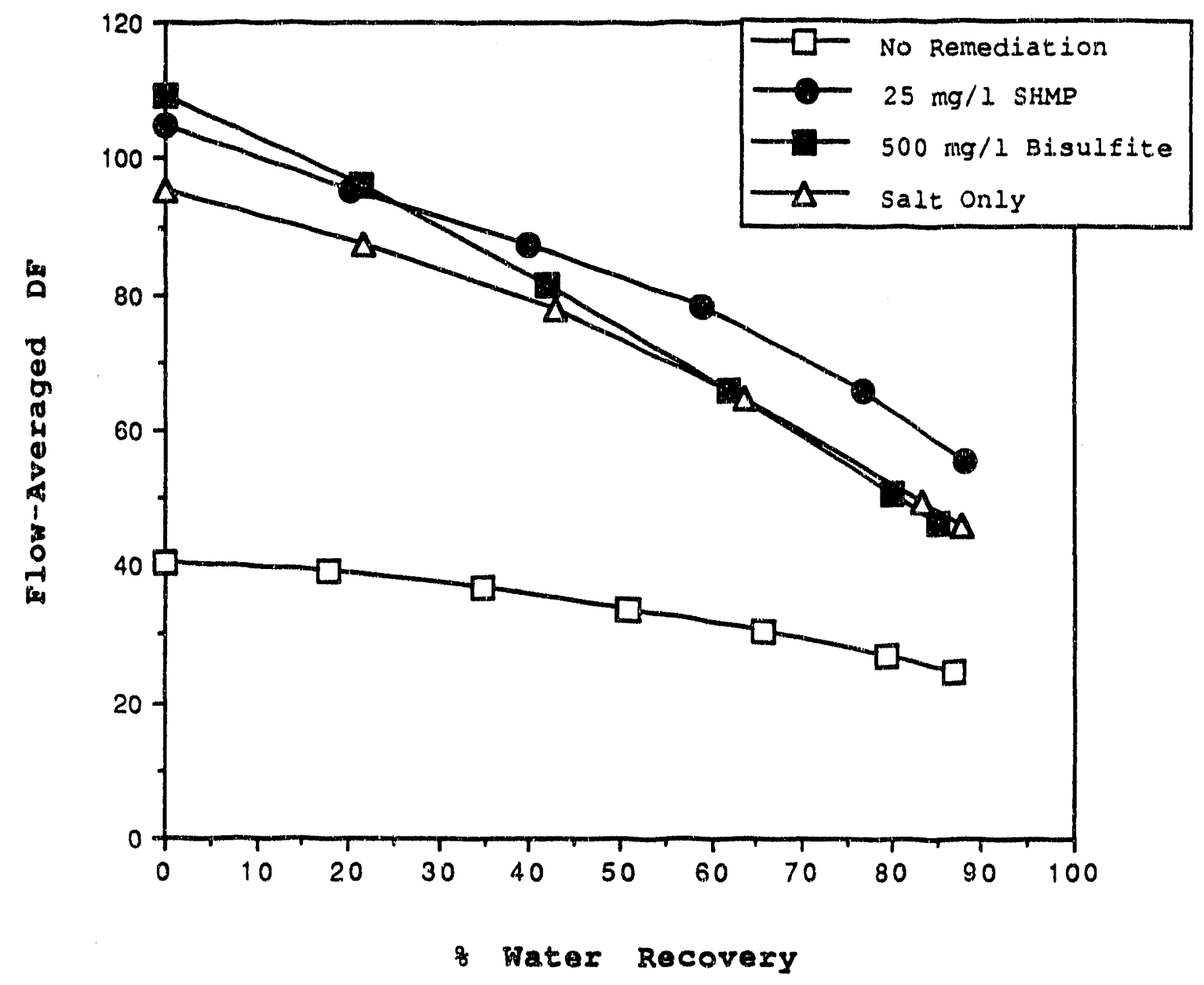

Figure 2. Remediation of DF Losses Due to Biofouling. 
D. I. EISH

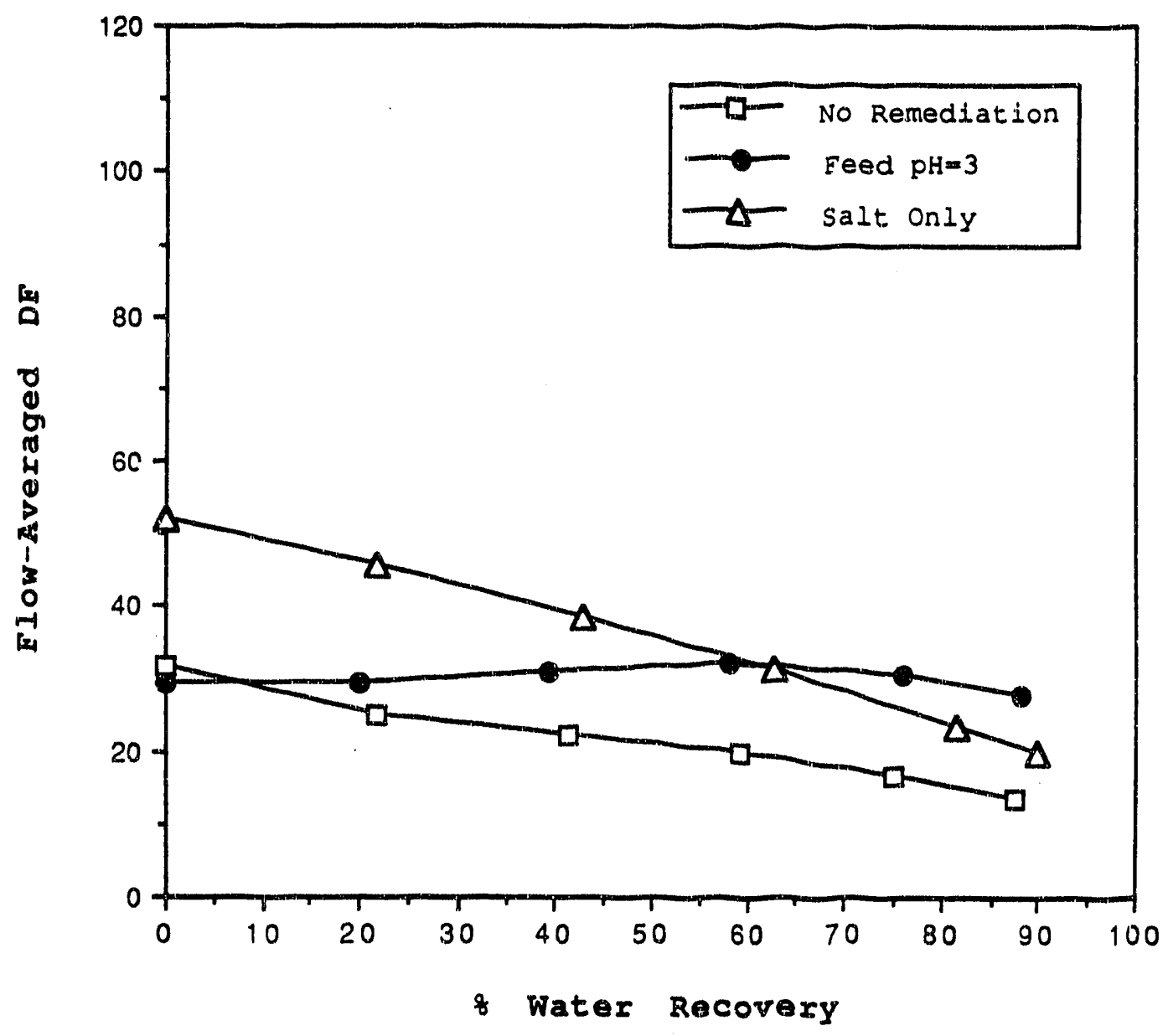

Figure 3. Romediation of DF Iosses by Feed pH Adjustments. 


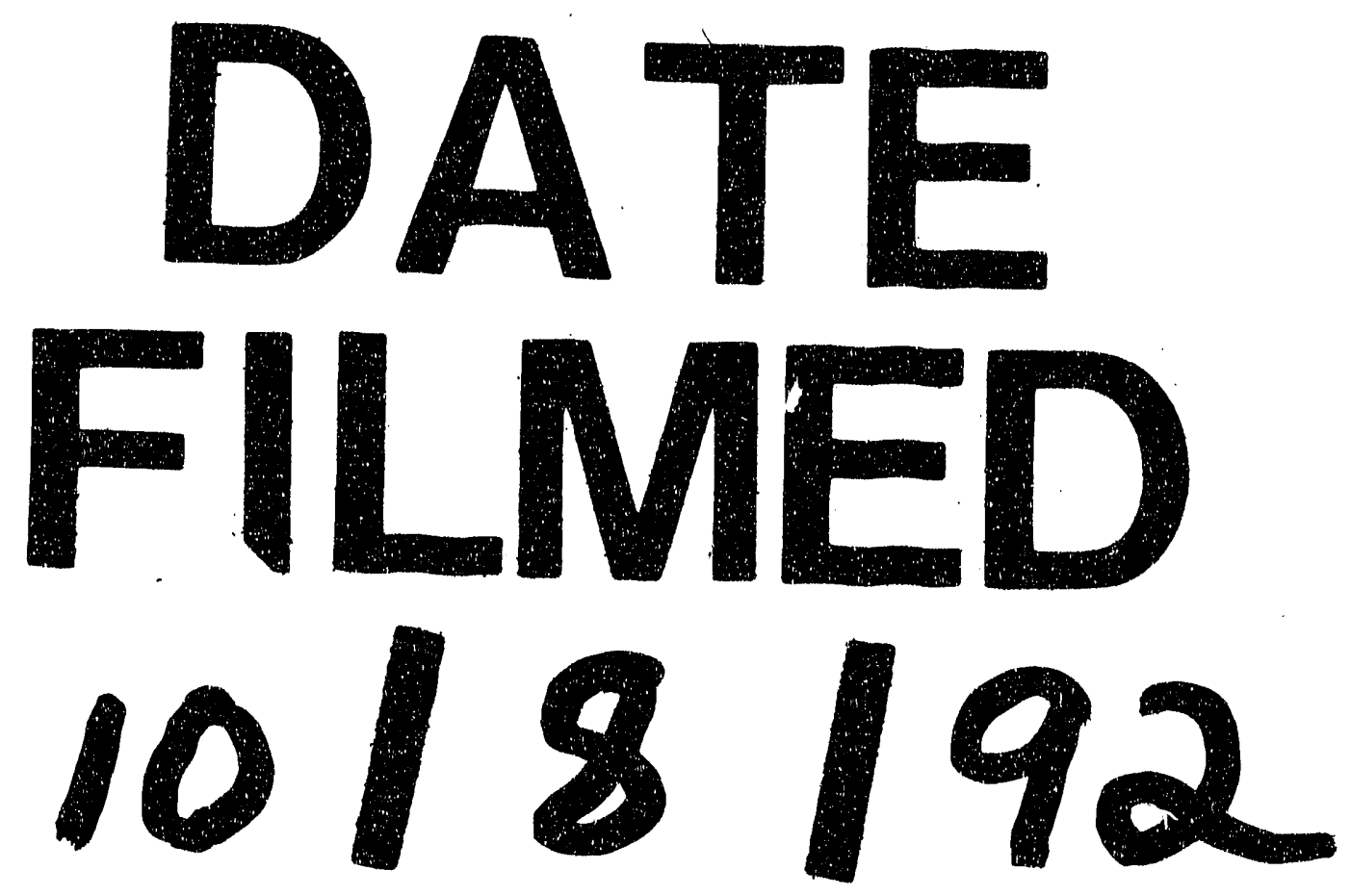


